\begin{tabular}{lr}
\hline \multicolumn{1}{c}{ D Y N A M I C E C O N O M E T R I C } & M O D E L S \\
DOI: http://dx.doi.org/10.12775/DEM.2016.004 & Vol. 16 (2016) 65-86 \\
\hline $\begin{array}{l}\text { Submitted October 25, 2016 } \\
\text { Accepted December 18, 2016 }\end{array}$ & ISSN (online) 2450-7067 \\
ISSN (print) 1234-3862
\end{tabular}

Andrzej Geise, Mariola Piłatowska*

\title{
Asymmetries in the Relationship between Economic Activity and Oil Prices in the Selected EU Countries**
}

\begin{abstract}
A b s t r a ct. In this paper the threshold (T-ECM) and linear (ECM) error correction models are estimated to examine the short-run and long-run Granger causality in terms of asymmetric and symmetric relationship for seven European Union economies (Germany, France, Denmark, the Netherlands, Poland, Czech Republic and the whole EU). The relationship between production, inflation and oil prices are analyzed in the presence of structural break when both, the change in intercept and the change in the slope of the trend function exist. Threshold ECMs show the asymmetric response of production and inflation to the changes in oil prices in the case of Germany, France, Poland and the EU. For other economies (Netherlands, Denmark and Czech Republic) the reaction was rather symmetric.
\end{abstract}

K e y w ords: short-run asymmetry, threshold cointegration, threshold error correction model, Granger causality, oil price shock.

J E L Classification: C32; E23; E32; Q43.

\section{Introduction}

Energy price shocks have important effects not only on economic activity but also on macroeconomic policy of industrialized countries. It is related to the essential meaning of energy in all areas of economic activities. Energy

\footnotetext{
* Correspondence to: . Andrzej Geise, Nicolaus Copernicus University, Faculty of Economic Sciences and Management, 13A Gagarina Street, 87-100 Toruń, Poland, e-mail: a.geise@umk.pl; Mariola Piłatowska, Nicolaus Copernicus University, Faculty of Economic Sciences and Management, 13A Gagarina Street, 87-100 Toruń, Poland, e-mail: mariola.pilatowska@umk.pl.

${ }^{* *}$ This work was financed from Faculty of Economic Sciences and Management research grant no. 2185-E.
}

(C) 2016 Nicolaus Copernicus University. All rights reserved.

http://www.dem.umk.pl/dem 
is pushing all developed and developing countries to ensure the long-term stable energy prices and energy supply. The stable price of energy and independent source of imported energy resources are crucial to the economic development. Huge and unexpected increases of energy prices can cause the inflation to rise and reduce real money balances. These changes have negative effects on consumption and economic output.

The purpose of this paper is to analyze the short- and long-term dynamics of oil prices, production and inflation in the selected EU countries in the presence of structural break due to the financial crisis. The potential asymmetries over the production are investigated, and then we examine the causality among the oil prices, production and inflation in the context of high and low growth regime.

First, the threshold cointegration analysis applied in Geise and Piłatowska (2014) for 7 European economies is extended to the case of structural break due to the financial crisis not only in an intercept but both intercept and trend coefficient. These results will be compared to those contained in the mentioned article.

Second, the Granger causality among oil prices, production and inflation in the selected EU countries (Germany, France, Netherlands, Denmark, Poland, Czech Republic and the European Union as well) is examined based on the linear ECM and threshold ECM models. In Geise and Piłatowska (2014) the relationships among explanatory variables were analyzed by the threshold error correction model with asymmetric adjustment process. Here, the relationships between production, inflation and oil prices are analyzed by both threshold ECM and linear ECM. When the threshold cointegration occurs, the threshold error correction model with asymmetric adjustment process and asymmetric short-run dynamics (T-ECM) is estimated. In other cases the linear ECM models are estimated. The threshold model allows us to identify the relationships among oil prices, production and inflation according to business cycle phases, i.e. the growth phase of the economic business cycle is defined as high growth regime (when the deviations from longrun equilibrium are above the threshold value) and the recession phase is related to low growth regime (when the deviations are below the threshold value).

The concept of a research study is presented in Scheme 1 .

The plan of this paper is as follows. Section 1 presents short theoretical explanations for symmetric and asymmetric reaction of economic activity to oil price shocks. Section 2 reviews the methodology applied in this paper. Section 3 shows the results of threshold cointegration analysis and presents 
empirical error correction models. Section 4 presents the results of Grangercausality analysis. The last section concludes.

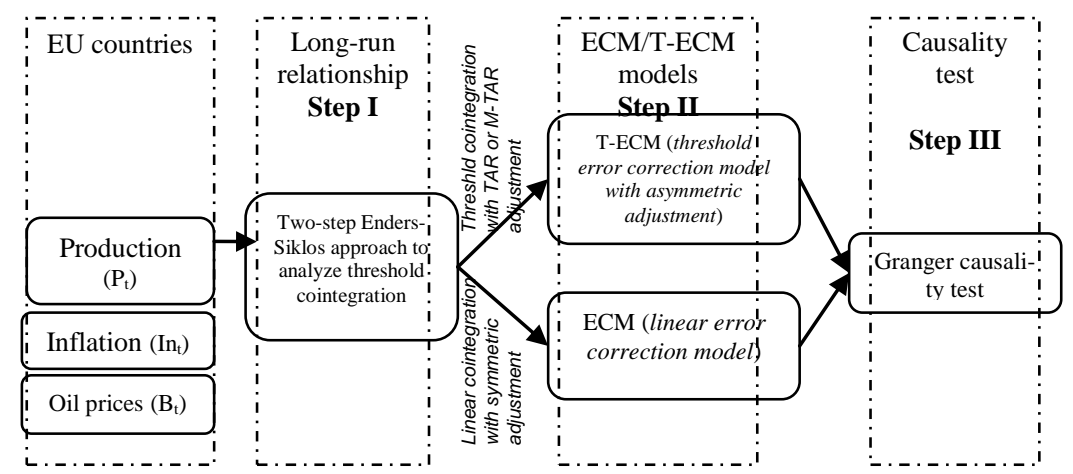

Scheme 1. Concept of the study the Granger causality among oil prices, production and inflation

\section{Asymmetries in the Transmission of Oil Price Shocks}

The nature of the relationship between oil prices and economic activity (symmetric or asymmetric) determines the way of oil prices modelling. It helps to understand the magnitude of positive and negative oil price shocks impact on economy and select the model of transmission of oil price shocks among alternative models. The study of transmission of oil price shocks should focus on whether the transmission channel leads to the symmetric or asymmetric response of economic activity in the context of oil importing and oil exporting countries.

Oil price shocks are transmitted to the economic activity by the direct supply-side channel. Increases in the prices of crude oil have a direct impact on the supply of crude oil and supply of high energy-consuming goods. Considering oil importing countries in which the production function can be expressed as a functional form of input factors (such as labour, capital and energy), it turns out that the large fluctuations in economic activity are unlikely to observe without a large fluctuation in the variation in energy prices. Also, when the smooth production function is assumed, the symmetric response of output to changes in energy input is observed (Hamilton, 2008).

The direct demand-side channel of oil price shock transmission for oil importing countries indicates that the increase of oil prices leads to changes in consumer's purchasing power. These changes are related to the income transfer from oil exporting countries to oil importing countries. Therefore, 
increases in oil prices will cause the increases in production (by the demand push) in oil exporting countries, however the oil importing countries will face the production decrease (Hamilton, 2011).

Both direct transmission mechanisms presents the direct and symmetric reaction of economic activity to changes in oil prices. However, some indirect transmission channels amplify the effect of oil price shock and may lead to an asymmetric reaction of economic activity.

The sectoral reallocation associated with capital and labour reallocation from energy-intensive sectors to expanding sectors is a result of a positive oil price shock. In the case of oil-importing countries, sectoral reallocation will reinforce the recessionary effect of oil price increasing (Davis and Haltiwanger, 2001). However Hamilton (1988) presents that the lower economic activity and higher unemployment rate are an outcome of the lack of sectoral reallocation. This disturbance is caused by workers who can be confident about the future improvement of their sector and decide not to relocate even if they are offered a job in a different sector. However, both types off reallocation disturbances will lead to an asymmetric reaction of production as a result of a positive or negative oil price shock.

Another explanation of an asymmetric reaction of economic activity to oil price shocks is connected with precautionary savings. For an oil importing economy the rise of oil price can cause the future decrease in employment and real income, inducing an increase in precautionary savings, which in turn leads to the decrease in production (Edelstein and Kilian, 2009).

For oil importing economies the asymmetric reaction of monetary policy to oil price increases and decreases is still ambiguous. For instance, Bernanke et al., (1997) pointed out the asymmetric reaction of the Federal Reserve to oil price shocks (authors show that the FED responds more aggressively to oil price increases than oil price decreases). However, some other authors argue that the reaction of monetary policy to oil price shocks is insignificant and doesn't exist - see e.g. Hamilton and Herrera, (2004).

The evidence consistent with the model of asymmetric reaction of economic activity to oil price shocks was provided by Herrera et al., (2015). Authors used data for 18 OECD countries and pointed out that the sectoral reallocation disturbances and the existence of a precautionary savings, when future employment level was uncertain, implied an asymmetric response of aggregate production. 


\section{Methods}

To test the threshold cointegration among production, inflation and Brent oil prices in the selected EU countries the Enders-Granger approach and the Enders-Siklos approach is employed ${ }^{1}$. This technique is a residual based two-stage estimation and focuses on the residuals from the long-run equilibrium relationship. For this study, the long-run relationship can be expressed as:

$$
P_{t}=\beta_{0}+\beta_{1} B_{t}+\beta_{2} \operatorname{In}_{t}+\beta_{3} D U_{t}^{*}(\lambda)+\beta_{4} D T_{t}^{*}(\lambda)+\varepsilon_{t},
$$

where $P_{t}, I n_{t}$ denote the industrial production index and consumer price index in selected economies respectively, $B_{t}$ stands for Brent crude oil prices; all variables are in natural logarithms; $\lambda$ refers to the time break, i.e., the period at which the change in the parameters of the intercept and trend function occurs, $D U_{t}^{*}(\lambda)$ is the dummy variable for the break in intercept of production function where $D U_{t}^{*}(\lambda)=1$ if $t>\lambda$ and 0 otherwise, $D T_{t}^{*}(\lambda)$ is the variable for a change in the slope of the trend function where $D T_{t}^{*}(\lambda)=t$ if $t>\lambda$ and 0 otherwise, $\beta_{0}, \beta_{1}, \beta_{2}, \beta_{3}, \beta_{4}$ are parameters to be estimated and $\varepsilon_{t}$ is the disturbance term that may be serially correlated.

Next, the analysis focuses on the estimation of $\rho_{1}$ and $\rho_{2}$ coefficients in the following regression:

$$
\Delta \varepsilon_{t}=I_{t} \rho_{1} \varepsilon_{t-1}+\left(1-I_{t}\right) \rho_{2} \varepsilon_{t-1}+\sum_{i=1}^{p} \alpha_{i} \Delta \varepsilon_{t-i}+u_{t}
$$

where $u_{t}$ is a white-noise disturbance, $p$ the number of lags, $\rho_{1}, \rho_{2}$ and $\alpha_{i}$ the coefficients, $\varepsilon_{t}$ in equation (2) is extracted from long-run equation (1). $I_{t}$ term is the Heaviside indicator function such that: $I_{t}=1$ if $\varepsilon_{t-d} \geq \tau$, and 0 otherwise (for TAR model); or $I_{t}=1$ if $\Delta \varepsilon_{t-d} \geq \tau$, and 0 otherwise (for M-TAR model) where $\tau$ is the threshold value.

The TAR model is designed to capture the potential asymmetric movements in residuals $\varepsilon_{t}$, while the M-TAR model is designed to capture the direction of the potential asymmetric movements (Fosten et. al, 2012). Negative deepness (i.e., $\left|\rho_{1}\right| \leq\left|\rho_{2}\right|$ ) of the residuals implies that increases of $\varepsilon_{t}$

\footnotetext{
${ }^{1}$ see Geise and Piłatowska (2014), Piłatowska, Włodarczyk and Zawada (2014).
} 
tend to persist, whereas decreases tend to revert quickly toward to equilibrium (Enders and Granger, 1998).

The threshold value $\tau$ can be set as zero or can be estimated according to the Chan's search method ${ }^{2}$. The estimation of the threshold parameter is not obvious. When the threshold parameter is known (equal 0), the simply OLS can be used to estimate the slope parameter $\beta=(\alpha, \rho)$ of equation (2). In the case of unknown threshold parameter the conditional LS must be used. To obtain an estimation minimizing the sum of squares or maximizing the log-likelihood, the OLS cannot be used, because as the objective function is highly erratic. A solution is obtained through concentration of the objective function. As the slope estimators given a threshold are the OLS one. The problem of using highly erratic function can be reduced by concentrating out the minimization problem through $\beta(\theta)$ and the corresponding sum of squares $\operatorname{SSR}(\theta)$. The objective function has the form:

$$
\widehat{\theta}=\arg \min _{\theta} \operatorname{SSR}(\theta) .
$$

Minimization of (3) is done through a grid search: the values of the variable are sorted, a certain percentage of the first and last values is excluded to ensure a minimal number of observations in each regime, the SSR is estimated for each selected value and the one that minimize the SSR is taken as the estimator (Stigler, 2010)

Before the threshold cointegration analysis is conducted, the Tsay linearity test is used to verify the null hypothesis of linearity in threshold variable for different value of delay $(d)$ - see more Tsay (1989).

Testing for threshold cointegration is performed in two steps. First, an $\Phi$-test is employed to examine the null hypothesis of no cointegration ( $H_{0}: \rho_{1}=\rho_{2}=0$ ) against alternative of cointegration with either TAR or MTAR threshold adjustment. Second, the test $F$-test is used to verify the null hypothesis of symmetric adjustment $\left(H_{0}: \rho_{1}=\rho_{2}\right)$. Rejection of both hypothesizes indicates the existence of threshold cointegration with an asymmetric adjustment (Enders and Siklos, 2001).

The threshold error correction model (with two regimes) has the form:

${ }^{2}$ see Chan (1993), Geise and Piłatowska (2014). 


$$
\begin{aligned}
& \Delta Y_{j t}=\alpha+\left(\gamma_{1} \varepsilon_{t-1}+\sum_{i=1}^{q_{1}} \delta_{i}^{*} \Delta P_{t-i}+\sum_{i=1}^{q_{2}} \theta_{i}^{*} \Delta I n_{t-i}+\sum_{i=1}^{q_{3}} \varphi_{i}^{*} \Delta B_{t-1}\right) \mathrm{I}_{t}\left\{\Theta_{t} \geq \tau\right\}+ \\
& +\left(\gamma_{2} \varepsilon_{t-1}+\sum_{i=1}^{q_{1}} \delta_{i} \Delta P_{t-i}+\sum_{i=1}^{q_{2}} \theta_{i} \Delta I n_{t-i}+\sum_{i=1}^{q_{3}} \varphi_{i} \Delta B_{t-1}\right)\left(1-\mathrm{I}_{t}\right)\left\{\Theta_{t} \geq \tau\right\}+\zeta_{t}
\end{aligned}
$$

where $\Delta Y_{j t}=\left(\Delta P_{t}, \Delta I n_{t}, \Delta B_{t}\right), \varepsilon_{t-1}$ represent the error correction terms, $\Theta_{t}$ is the threshold variable, which is a continuous and stationary transformation of the data and takes the form of $\varepsilon_{t-d}$ (when TAR adjustment mechanism is used) or $\Delta \varepsilon_{t-d}$ (when M-TAR adjustment mechanism is selected), $\tau \in \Gamma$ is the threshold parameter.

When the method proposed by Enders and Siklos (2001) cannot reject the hypothesis of symmetric cointegration the linear error correction model is estimated. The structure of model is determined by the following equation:

$$
\Delta Y_{j t}=\alpha+\gamma_{1} \varepsilon_{t-1}+\sum_{i=1}^{q_{1}} \delta_{i} \Delta P_{t-i}+\sum_{i=1}^{q_{2}} \theta_{i} \Delta I n_{t-i}+\sum_{i=1}^{q_{3}} \varphi_{i} \Delta B_{t-1}+\mu_{t}
$$

where $\varepsilon_{t-1}$ is obtained from the estimated long-run equation (1) and $\mu_{t}$ is a white noise disturbance.

\section{Linear (ECM) and Threshold Error correction Models (T-ECM) of Production, Inflation and Oil Prices in the Selected EU Countries}

In this section, the threshold cointegration analysis, threshold (T-ECM) and linear error correction models (ECM) for production, inflation and oil prices in Germany, France, the Netherlands, Denmark, Poland, Czech Republic and the European Union are discussed. To investigate the presence of asymmetries in the relationship between oil prices and economic activity the monthly data from January 1995 to April 2014 are used. In particular, industrial production index at constant prices of 2010, consumer price index and Brent oil prices (each time series expressed in natural logarithms) were used $^{3}$. The results of the ADF test revealed that all analyzed series were integrated of first order, $I(1)$ - see Geise and Piłatowska (2014). Therefore, in further analysis the first differences of each series are used.

The structural break occurred due to the financial crisis peaked in 2008 may change the nature of the long-run equation for production. Therefore we

\footnotetext{
${ }^{3}$ Here, the identical sets of variables as in Geise and Piłatowska (2014) were used.
} 
assume the long-term relationship with both one-time change in the intercept and change in the slope of the trend function (as in Perron, 1989).

To motivate the use of long-term relationship (with structural break in September 2008), we display the time series for production in analyzed economies in Figure 1 with the fitted values of the regression $\tilde{P}_{t}=\tilde{\mu}+\tilde{\gamma}_{1} D U_{t}+\tilde{\beta}_{1} t+\tilde{\gamma}_{2} D T_{t}+v_{t}$, estimated by the OLS, where $D U_{t}=D T_{t}=0$ if $t \leq 2008: 09$ and $D U_{t}=1, D T_{t}=t$ if $t>2008: 09$.

As we can see in Figure 1 the production index for all analyzed economies has an upward trend. However when the financial crisis occurs (in 2008-2009) the line slopes downward and the production index is falling. After 2009, production index returns to the pre-crisis path but at a slower pace than previously. Figure 1 reveals that the production response to the global financial crisis is higher in developed countries (i.e., Germany, France, Denmark, European Union) and lower in developing countries (i.e., Poland and Czech Republic).

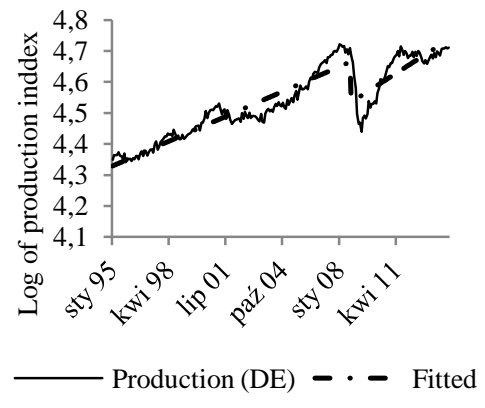

a) Logs in production in Germany

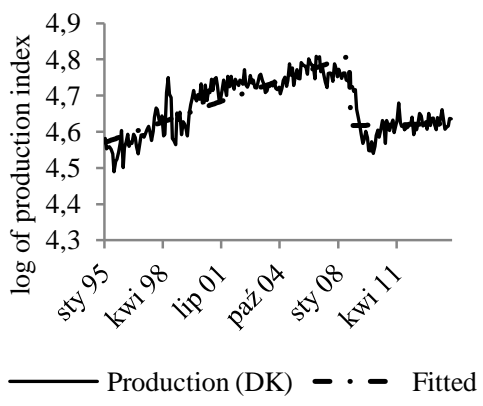

c) Logs in production in Denmark

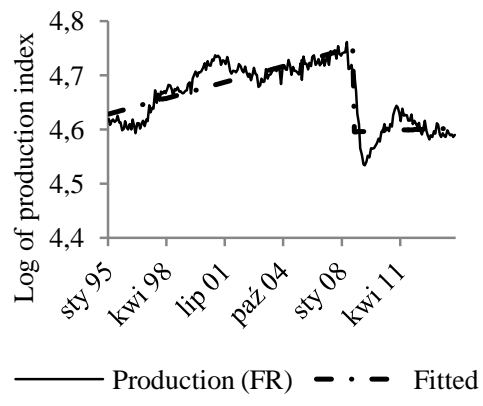

b) Logs in production in France

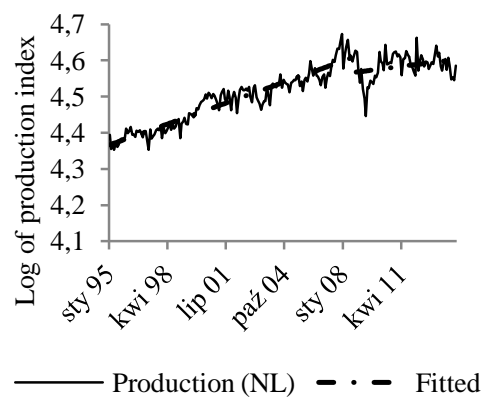

d) Logs in production in Netherlands 


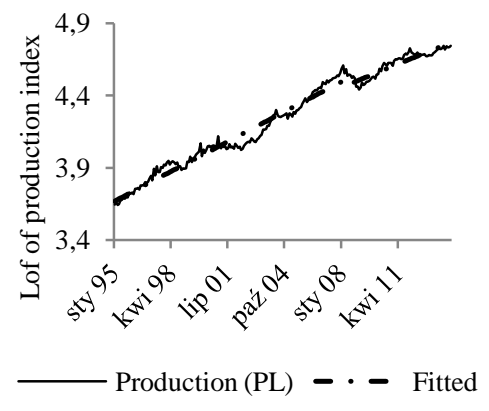

e) Logs in production in Poland

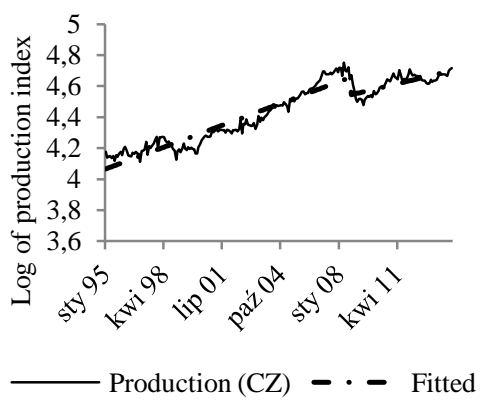

f) Logs in production in Czech Rep.

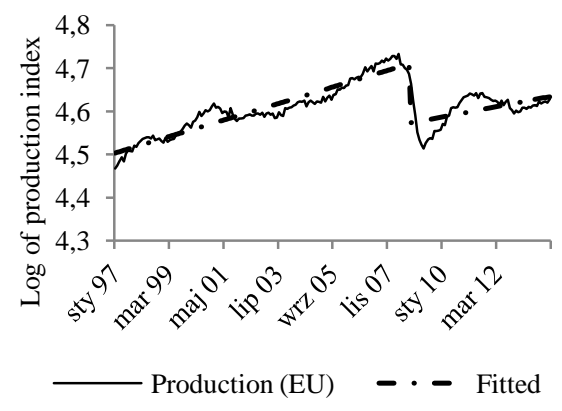

g) Logs in production in European Union

Figure 1. Logs in production and fitted trend line with break for selected EU countries

This findings reveal that the structural changes in production caused by the global financial crisis are more apparent in developed economies than in developing economies. The break point (set in September 2008) refers to the time of break, i.e., the period at which the change in the level of series (break in intercept) and lower growth rate (the change in the slope of a trend function) occur. In the case of Germany, France, Denmark and European Union the production response to the financial crisis is sudden and significant. For other economies (the Netherlands, Poland and Czech Republic) the change in production index is small but visible - see Figure 1. The estimated parameters $\beta_{3}$ and $\beta_{4}$ for all economies are statistically significant what is an argument for taking into account both a sharp change in the level of the series (break in intercept) and the change in the slope of a trend function - see Table 1. 
Table 1. The ADF test for cointegration

\begin{tabular}{|c|c|c|c|c|c|c|c|}
\hline \multirow{2}{*}{ Country } & \multicolumn{6}{|c|}{ Estimated parameters of long-run equation with structural break } & \multirow{2}{*}{$\begin{array}{c}\text { ADF } \\
\text { Levels }(C+t)\end{array}$} \\
\hline & Const. & $\ln _{t}$ & $\mathrm{~B}_{\mathrm{t}}$ & time & $\mathrm{DU}_{\mathrm{t}}(\lambda)$ & $\mathrm{DT}_{\mathrm{t}}(\lambda)$ & \\
\hline \multirow[t]{2}{*}{$\mathrm{DE}$} & -9.935 & 3.077 & 0.022 & 0.0017 & -0.0992 & 0.0008 & -3.573 \\
\hline & & [7.218] & {$[2.166]$} & [14.58] & {$[-10.24]$} & [3.778] & $(0.006)^{* * *}$ \\
\hline \multirow[t]{2}{*}{ FR } & 0.498 & 0.911 & -0.0302 & 0.001 & -0.16 & -0.0005 & -3.882 \\
\hline & & [3.334] & {$[-4.144]$} & [12.13] & {$[-21.92]$} & {$[-3.18]$} & $(0.002) * * *$ \\
\hline \multirow[t]{2}{*}{$\mathrm{NL}$} & -0.262 & 0.979 & 0.038 & 0.001 & -0.0329 & -0.001 & -4.673 \\
\hline & & [4.452] & {$[5.746]$} & [12.83] & {$[-4.37]$} & {$[-6.502]$} & $(<0.01)^{* * *}$ \\
\hline \multirow[t]{2}{*}{ DK } & -2.735 & 1.614 & -0.066 & 0.0022 & -0.220 & -0.0009 & -4.323 \\
\hline & & [4.425] & {$[-6.811]$} & [17.86] & {$[-21.36]$} & {$[-4.425]$} & $(0.001)^{* * *}$ \\
\hline \multirow[t]{2}{*}{$\mathrm{PL}$} & 2.33 & 0.256 & 0.044 & 0.005 & 0.163 & -0.001 & -2.986 \\
\hline & & [2.103] & [2.761] & [15.95] & [3.24] & [-4.892] & $(0.036)^{* *}$ \\
\hline \multirow[t]{2}{*}{$\mathrm{CZ}$} & -1.597 & 1.17 & 0.072 & 0.003 & -0.114 & -0.002 & -4.051 \\
\hline & & [10.61] & [7.16] & [22.13] & {$[-10.65]$} & {$[-6.959]$} & $(0.001)^{* * *}$ \\
\hline \multirow[t]{2}{*}{ EU } & 0.786 & 0.792 & 0.017 & 0.001 & -0.043 & -0.0006 & -3.044 \\
\hline & & [4.023] & [1.947] & [9.449] & {$[-1.833]$} & {$[-4.353]$} & $(0.031)^{* *}$ \\
\hline
\end{tabular}

Note: $* * *, * *$ and $*$ denote significance at $1 \%, 5 \%$ and $10 \%$ level respectively; in parentheses the $p$-value are given, in brackets the $t$-statistics are given.

Before estimating the model, it is necessary to check whether the relationships between the variables are characterized by non-linearity. The Tsay method is employed to test for linearity of time series. In order to test for linearity of series, the optimal autoregression lag of model should be determined. For Germany and Poland the optimal lag $p$ is equal to 1, for France and the EU the lag $p$ is equal to 5. For Denmark, Netherlands and Czech Republic the optimal lag $p$ is respectively equal to 3,1 and 2. Table 2 summarizes the result of linearity test. The $F(p, d)$ statistic suggest that the time series for Germany, Denmark and Poland are nonlinear with $d=1$ (it appears that the threshold break with delay greater than 1 in the case of Germany is possible, however the threshold break with delay $d=1$ as the threshold variable showing the greatest effect). In the case of France and the EU the Tsay test rejects the linear hypothesis with delay $d=5$ with the greatest effect. For Netherlands the threshold delay is equal to 11 and for Czech Republic the Tsay test does not reject the null hypothesis of linear relationship - see Table 2 .

When we allow the structural break in intercept and slope of trend function in long-run equation (1), the linear cointegration test reveals the longrun relationship for all analyzed economies - see Table 1. However, the Engle-Granger approach assuming symmetric adjustment toward equilibrium is misspecified if the adjustment is asymmetric. Therefore, to test for cointegration with asymmetric adjustment, the threshold cointegration approach proposed by Enders and Sikols (2001) is used. 
Table 2. The Tsay (1989) linearity test

\begin{tabular}{cccccccc}
\hline $\begin{array}{c}\text { Delay } \\
d\end{array}$ & $\begin{array}{c}\text { Germany } \\
(\mathrm{DE})\end{array}$ & $\begin{array}{c}\text { France } \\
(\mathrm{FR})\end{array}$ & $\begin{array}{c}\text { Denmark } \\
(\mathrm{DK})\end{array}$ & $\begin{array}{c}\text { Neder- } \\
\text { land (NL) }\end{array}$ & $\begin{array}{c}\text { Poland } \\
(\mathrm{PL})\end{array}$ & $\begin{array}{c}\text { Czech } \\
\text { Republic } \\
(\mathrm{CZ})\end{array}$ & $\begin{array}{c}\text { European } \\
\text { Union } \\
(\mathrm{EU})\end{array}$ \\
\hline 1 & $\mathbf{9 . 6 6 0 ^ { * * }}$ & $4.176^{* *}$ & $4.632^{* *}$ & 0.634 & $\mathbf{6 . 9 6 0} * *$ & 1.183 & $4.620^{* *}$ \\
2 & 2.009 & $5.719^{* *}$ & 0.765 & 1.126 & 2.787 & 2.446 & $5.011^{* *}$ \\
3 & $5.394^{* *}$ & $3.376^{* *}$ & 0.064 & 0.682 & 1.095 & 0.902 & $3.240^{* *}$ \\
4 & 2.598 & 0.969 & 1.021 & 0.568 & 0.527 & 0.946 & 1.788 \\
5 & $1.754^{* *}$ & $\mathbf{6 . 2 9 4}{ }^{* *}$ & 1.190 & 0.309 & 0.577 & 1.055 & $9.086^{* *}$ \\
6 & 0.417 & 1.112 & $4.373^{* *}$ & 0.277 & 1.185 & 0.796 & 1.138 \\
7 & 2.741 & 0.909 & 1.306 & 0.552 & 0.086 & 1.256 & $4.458^{* *}$ \\
8 & 0.546 & 1.887 & $2.341^{*}$ & 1.825 & 0.314 & 0.796 & $4.151^{* *}$ \\
9 & 2.236 & $2.232^{* *}$ & 0.211 & 0.917 & 0.049 & 0.306 & 2.532 \\
10 & 1.471 & 0.961 & 0.965 & $2.750^{* *}$ & 0.020 & 1.831 & 0.900 \\
11 & 0.391 & 1.035 & 0.831 & $3.499 * *$ & 0.895 & 0.687 & 0.931 \\
12 & $7.141^{* *}$ & 0.334 & 0.902 & 1.664 & 0.503 & 0.144 & 0.411 \\
\hline Note: $* *$ indicates the rejection of null hypothesis at the 5\% significance level. & &
\end{tabular}

The asymmetric adjustment mechanism (TAR or M-TAR) is selected using the Akaike information criterion (AIC). Threshold cointegration test finds the evidence for threshold mechanism in the case of Germany, France, Poland and the European Union (both the null hypothesis of no cointegration $\left(H_{0}: \rho_{1}=\rho_{2}=0\right)$ and the null of symmetric adjustment $\left(H_{0}: \rho_{1}=\rho_{2}\right)$ are rejected). Here the M-TAR model with zero-value of threshold is used. For three other countries (Denmark, Netherlands and Czech Republic) the symmetric cointegration is found (only the null hypothesis of no cointegration is rejected but the null of symmetric adjustment is not rejected) - see Table A.1 in appendix.

The selection of M-TAR model indicates that the direction in which production is moving (its momentum) is more important than whether deviations from long-run equation are above or below the equilibrium (as in TAR model).

In the case of mentioned economies (Germany, France, Poland and the EU) the point estimates $\rho_{1}$ and $\rho_{2}$ have negative signs. It means that adjustment coefficients act to eliminate deviations from long-run relationship. For Germany, France and the EU deviations below the threshold adjust faster toward the long-run equilibrium than the deviations above the threshold $\left(\left|\rho_{1}\right|<\left|\rho_{2}\right|\right)$. We can see that respectively $22.0 \%, 21.7 \%$ and $26.2 \%$ of the deviation from equilibrium is corrected in the next period when they are below the threshold, but only $0.8 \%, 7.3 \%$ and $5.9 \%$ when they are above the threshold. In the case of Poland the deviation above the threshold adjusts faster toward the long-term equilibrium (16.1\% of deviation in the next peri- 
od is corrected) than deviations below the threshold (only $4.9 \%$ of deviation is corrected).

These results showed that the threshold cointegration occurs for developed countries (Germany, France and the EU). In the case of Poland the threshold cointegration also occurs, however it should be noted, that the value of adjustment coefficient in regime 1 is greater than regime 2 (since $\left.\left|\rho_{1}\right|>\left|\rho_{2}\right|\right)$. Results for Poland are inconsistent with the theory, where the greater value of coefficient $\left|\rho_{2}\right|$ provides confirmation of the faster reversion to the long-run equilibrium when the deviations from long-run equation are below the threshold value and the slowdown of economic activity (recession in business cycle) is mitigated by the interaction of fiscal and monetary policy. Some other mitigating factors of recession can be distinguished as follows: interaction between foreign trade and domestic economy or dynamic expansion of the service-sector characterized by the greater resilience to temporary downturn in economic activity (Orłowska, Pangsy-Kania, 2003).

Given the findings of linearity test and threshold cointegration among oil prices, production and inflation, it is possible to estimate the threshold (T-ECM) and linear error correction models (ECM). The results of the threshold ECMs for German, France, Poland and the European Union economies are reported in Table 4. In this case, the M-TAR-ECM models for Germany, France, Poland and the European Union take the form of equation (5).

Parameters of an asymmetric adjustment of threshold models are presented in Table 3. The results for Denmark, Netherlands and Czech Republic are presented in Table 4.

Table 3. Adjustment coefficients $\left(\gamma_{1}\right.$ and $\left.\gamma_{2}\right)$ of the estimated M-TAR-ECM (with $\tau=0$ ) models for the selected EU countries

\begin{tabular}{cccccc}
\hline Regime & Variables & Germany (DE) & France (FR) & European Union (EU) & Poland (PL) \\
\hline \multirow{2}{*}{ High } & $\Delta \mathrm{P}_{\mathrm{t}}$ & $-0.047[-0.93]$ & $0.052[0.52]^{* *}$ & $-0.002[-0.02]$ & $-0.14[-2.65]^{* * *}$ \\
growth & $\Delta \mathrm{n}_{\mathrm{t}}$ & $0.013[1.432]$ & $0.045[2.08]^{* *}$ & $0.005[0.27]$ & $0.011[0.99]$ \\
& $\Delta \mathrm{B}_{\mathrm{t}}$ & $-0.142[-0.46]$ & $0.788[1.07]$ & $0.234[0.33]$ & $0.269[1.15]$ \\
\hline \multirow{2}{*}{ Low } & $\Delta \mathrm{P}_{\mathrm{t}}$ & $-0.193[-4.16]^{* * *}$ & $-0.106[-2.46]^{* *}$ & $-0.117[-3.35]^{* * *}$ & $-0.03[-0.54]$ \\
\multirow{2}{*}{ growth } & $\Delta \mathrm{n}_{\mathrm{t}}$ & $0.015[1.75]^{*}$ & $0.003[0.32]$ & $0.014[1.51]$ & $0.016[1.41]$ \\
& $\Delta \mathrm{B}_{\mathrm{t}}$ & $0.143[0.494]$ & $-0.203[-0.64]$ & $0.333[0.86]$ & $-0.312[-1.30]$ \\
\hline
\end{tabular}

Note: ***, $(* *),(*)$ indicate significance at $1 \%,(5 \%)$ and $(10 \%)$ level, $t$-statistics for $\gamma_{1}$ and $\gamma_{2}$ in brackets, the Ljung-Box statistic for all estimated models show the lack of autocorrelation - the full results are available from the authors.

The M-TAR-ECM model allows for a different speed of adjustment to the long-run equilibrium depending on high- or low growth states of the 
economy (i.e. production is above or below the long-run relationship respectively).

The point estimates of $\gamma_{1}$ and $\gamma_{2}$ in the M-TAR-ECM models for $\Delta P_{t}$ have a negative sign but the coefficients of low growth regime $\left(\gamma_{2}\right)$ are significant in the case of Germany, France and the EU. In the case of Poland, the coefficient $\gamma_{1}$ (in high growth regime) is significant - see Table 3 .

The adjustment coefficients $\gamma_{1}$ and $\gamma_{2}$ in the model for $\Delta P_{t}$ in Germany, France and the EU suggest that the speed of adjustment is more rapid for negative than for positive discrepancies (since $\left|\gamma_{1}\right|<\left|\gamma_{2}\right|$ ). In the case of German economy about $19.3 \%$ (for France $10.6 \%$ and for the EU 11.7\%) of the deviation from equilibrium is corrected in the next period when production is falling, compared to about $4.7 \%$ (France $-5.2 \%$ and the EU $-0.2 \%$ ) when production is rising ${ }^{4}$ - see Table 3 . The greater value of coefficient $\left|\gamma_{2}\right|$ than $\left|\gamma_{1}\right|$ provides confirmation that the business cycle is characterized by a shorter low growth phase. It means that the recession phase is mitigated (for example by effective interaction of fiscal and monetary policies - see Orłowska, Pangsy-Kania, 2003, p. 24) because the greater value of $\left|\gamma_{2}\right|$, the faster correction of deviations from long-run equilibrium is observed. In the case of Poland the results reported in Table 3 show that the production deviations above the threshold adjust faster toward the long-run equilibrium than the deviations below the threshold (since $\left|\gamma_{1}\right|>\left|\gamma_{2}\right|$ ). We can see that only $3.0 \%$ of the production deviations from equilibrium are corrected in the next period when they are below the threshold, but $14.0 \%$ when they are above the threshold.

As can be seen in Table 3 the $\gamma$ coefficients in the threshold models for $\Delta I n_{t}$ and $\Delta B_{t}$ in Germany, France, Poland and the EU have a positive signs. That means the deviations to the long-run equation adjust to the 'wrong' direction (have positive signs) in either or both regimes, and additionally parameters $\gamma_{1}$ and $\gamma_{2}$ are not always significant.

\footnotetext{
${ }^{4}$ In Geise and Piłatowska (2014), when the long-run equation (cointegration relationship) allows for a one-time change in the intercept of the trend function, the point estimates of $\gamma_{1}$ and $\gamma_{2}$ in models for $\Delta \mathrm{P}_{\mathrm{t}}$ in German's economy suggest that the speed of adjustment is more rapid for positive than for negative discrepancies (since $\left.\left|\gamma_{1}\right|>\left|\gamma_{2}\right|\right)$. When the long-run specification allows for the change in the intercept and the change in the slope of the trend function the M-TAR-ECM model for $\Delta \mathrm{P}_{\mathrm{t}}$ in German's economy reveals consistent dependencies $\left(\left|\gamma_{1}\right|<\left|\gamma_{2}\right|\right)$.
} 
As can be seen in Table 4 (the results for linear ECM), only in the case of Denmark the deviation away from the long-run relationship is corrected not only by movements in production, but also by movements in inflation and oil prices. This can be seen by the negative signs and significance of the error correction coefficient $\gamma_{1}$ in the ECMs for $\Delta P_{t}, \Delta I n_{t}$ and $\Delta B_{t}$. For Netherlands and Czech Republic only in models for $\Delta P_{t}$ a negative and statistically significant sign is observed. It means that the long-run equilibrium is restored only by the short-run movements in production.

Table 4. Adjustment coefficients of the estimated ECM models for the selected EU countries

\begin{tabular}{cccc}
\hline Variables & Denmark (DK) & Netherlands (NL) & Czech Republic (CZ) \\
\hline$\Delta \mathrm{P}_{\mathrm{t}}$ & $-0.272[-3.63]^{\star * *}$ & $-0.669[-6.35]^{* * *}$ & $-0.174[-2.82]^{\star * *}$ \\
$\Delta \mathrm{In}_{\mathrm{t}}$ & $-0.014[-1.91]^{*}$ & $0.021[2.88]^{* * *}$ & $0.03[2.98]^{* * *}$ \\
$\Delta \mathrm{B}_{\mathrm{t}}$ & $-0.467[-2.13]^{* *}$ & $0.257[0.88]$ & $0.561[3.04]^{* * *}$ \\
\hline
\end{tabular}

Note: $* * *,(* *),(*)$ indicate significance at $1 \%,(5 \%)$ and $(10 \%)$ level, $t$-statistics for $\gamma_{1}$ and $\gamma_{2}$ in brackets, the Ljung-Box statistic for all estimated models show the lack of autocorrelation - the full results are available from the authors.

To summarize, the discussed results from threshold error correction model (M-TAR-ECM) confirmed the previous findings with regard to cointegration with asymmetric adjustment for deviations in production in the case of all analyzed economies (Germany, France, the EU and Poland). This can be seen by statistical significance of either adjustment coefficients which are properly signed. The Enders-Siklos procedure pointed out that the linear cointegration (symmetric adjustment) occurs for Netherlands, Denmark and Czech Republic. Also, the results of Engle-Granger test confirms these findings.

\section{Granger Causality Test Based on Linear and Threshold Error Correction Model}

In the previous section both the threshold error correction models (T-ECM) and linear error correction models (ECM) were estimated. Next, the Granger causality test is used to investigate the causal relationship among production, inflation and oil prices in the selected EU countries in the context of short- and long-run asymmetries.

The $F$-statistics for Granger causality is employed to examine whether all the coefficients of a given first differenced variable are jointly statistically different from zero (short-run causality) and whether the $\gamma_{1}, \gamma_{2}$ coefficients of error correction term are significant (long-run causality). Moreover, the 
jointly significance of the $\gamma$ coefficients and all the coefficients of a given explanatory variable is tested. The threshold error correction models allows us to distinguish between short- and long-run Granger causality in the context of high growth and lower growth state of the economy.

Table 5 and 6 present the results of the Granger-causality test based on the T-ECM and ECM models for oil prices, inflation and production.

The results of Granger-causality test, based on the threshold ECM models for Germany, show that there is short-run unidirectional causal relationship running from oil prices $\left(B_{t}\right)$ to inflation $\left(I_{t}\right)$ in both economic activity regimes (in the case of France the unidirectional relationship is identified in high momentum period and for the EU economy causal relationship is found in low momentum period). Unidirectional causal relationship between oil prices and production exists for the EU in both regimes (for France the unidirectional short-run causality running from oil prices to production is identified in the high momentum period). Bidirectional short-run causal relationship between oil prices, production and inflation exists for Polish economy in high growth regime - see Table 5. The result of Granger-causality test for Poland should be treated with precaution because the impact of Polish economy on the world crude oil prices does not exist. However short-run asymmetric reaction of inflation and production to oil price increases is highly probable. In the case of short-run causality the T-ECM models are able to identify the significance causal relationship from inflation to production for Germany in high momentum period (regime 1) - see Table 5.

The results of Granger-causality test, based on linear ECM models show that there is short-run unidirectional causal relationship running from oil prices to production and inflation in the case of Denmark (in the case of Czech Republic the unidirectional relation from $B_{t}$ to $I n_{t}$ is identified). For Netherlands the short-run causal relationship between explanatory variables is not confirmed - see Table 6 .

In terms of long-run situation, a unidirectional strong causal relationship running from oil prices $B_{t}$ to production $P_{t}$ is found in the case of all analyzed economies. The asymmetric models show that the oil prices affect the production in a high growth regime (when the production is in upward path) in the case of Poland, and in low growth regime (when the production is decreasing) in the case of Germany, France and the EU. For Denmark, Netherlands and Czech Republic the long-term linear relationship from oil prices to production (in the case of Denmark also to inflation) exists. This means that oil prices, among explanatory variables, contribute the most to the short- 
run adjustment to re-establish the long-run equilibrium in the case of all analyzed economies.

Table 5. Granger causality analysis based on threshold ECM models

\begin{tabular}{|c|c|c|c|c|c|c|c|c|}
\hline \multirow{3}{*}{ 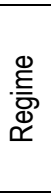 } & \multirow{3}{*}{ 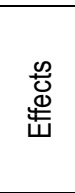 } & \multicolumn{7}{|c|}{ Causes } \\
\hline & & \multicolumn{3}{|c|}{ Short-term } & \multirow{2}{*}{$\begin{array}{c}\begin{array}{c}\text { Long- } \\
\text { term }\end{array} \\
\text { ecmt-1 }\end{array}$} & \multicolumn{3}{|c|}{ Both (short-term and long-term) } \\
\hline & & $\Delta \mathrm{P}_{\mathrm{t}}$ & $\Delta \mathrm{ln}_{\mathrm{t}}$ & $\Delta \mathrm{B}_{\mathrm{t}}$ & & $\begin{array}{c}\left(\Delta \mathrm{P}_{\mathrm{t}}\right. \\
\left.\mathrm{ecm_{ \textrm {t } - 1 }}\right)\end{array}$ & $\begin{array}{c}\left(\Delta \mathrm{ln}_{\mathrm{t}},\right. \\
\left.\mathrm{ec} \mathrm{t}_{\mathrm{t}-1}\right)\end{array}$ & $\begin{array}{c}\left(\Delta \mathrm{B}_{\mathrm{t}},\right. \\
\left.\mathrm{ecm} \mathrm{t}_{\mathrm{t}-1}\right)\end{array}$ \\
\hline \multicolumn{9}{|c|}{ Germany (DE) } \\
\hline \multirow{3}{*}{ I } & $\Delta \mathrm{P}_{\mathrm{t}}$ & - & $4.823^{* *}$ & 1.187 & 0.876 & - & 2.538 * & 0.968 \\
\hline & $\Delta \mathrm{ln}_{\mathrm{t}}$ & 0.167 & - & $15.12^{* * *}$ & 2.05 & 1.025 & - & $9.055^{* * *}$ \\
\hline & $\Delta \mathrm{B}_{\mathrm{t}}$ & 0.238 & 0.374 & - & 0.21 & 0.301 & 0.364 & - \\
\hline \multirow{3}{*}{$\|$} & $\Delta \mathrm{P}_{\mathrm{t}}$ & - & 1.069 & 1.705 & $17.31^{\text {*** }}$ & - & $5.035^{* * *}$ & $6.603^{* * *}$ \\
\hline & $\Delta \mathrm{ln}_{\mathrm{t}}$ & 1.337 & - & $2.513^{*}$ & $3.067^{*}$ & 1.913 & - & 2.538 ** \\
\hline & $\Delta \mathrm{B}_{\mathrm{t}}$ & $2.714^{* *}$ & 0.52 & - & 0.244 & $2.152 *$ & 0.454 & - \\
\hline \multicolumn{9}{|c|}{ France (FR) } \\
\hline \multirow{3}{*}{ I } & $\Delta \mathrm{P}_{\mathrm{t}}$ & - & 0.179 & $5.344^{* *}$ & 0.266 & - & 0.923 & $2.869^{*}$ \\
\hline & $\Delta \mathrm{ln}_{\mathrm{t}}$ & 0.482 & - & $11.05^{* * *}$ & $4.313^{* *}$ & 2.156 & - & 8.036 *** \\
\hline & $\Delta \mathrm{B}_{\mathrm{t}}$ & 0.206 & 1.794 & - & 1.453 & 0.575 & 1.171 & - \\
\hline \multirow{3}{*}{$\|$} & $\Delta \mathrm{P}_{\mathrm{t}}$ & - & 0.823 & 1.215 & 6.036 ** & - & 1.41 & 1.94 ** \\
\hline & $\Delta \mathrm{ln}_{\mathrm{t}}$ & 1.333 & - & 1.607 & 0.104 & 1.384 & - & 1.433 \\
\hline & $\Delta \mathrm{B}_{\mathrm{t}}$ & 1.144 & 1.21 & - & 0.415 & 1.039 & 1.1 & - \\
\hline \multicolumn{9}{|c|}{ European Union (EU) } \\
\hline \multirow{3}{*}{ I } & $\Delta \mathrm{P}_{\mathrm{t}}$ & - & 0.924 & 2.966 * & 0.982 & - & 0.472 & 1.543 \\
\hline & $\Delta \mathrm{ln}_{\mathrm{t}}$ & 0.015 & - & 12.08 *** & 0.072 & 0.059 & - & $6.56^{* \star *}$ \\
\hline & $\Delta \mathrm{B}_{\mathrm{t}}$ & 0.539 & 0.043 & - & 0.109 & 0.275 & 0.091 & - \\
\hline \multirow{3}{*}{$\|$} & $\Delta \mathrm{P}_{\mathrm{t}}$ & - & 0.468 & $2.533^{*}$ & $11.23^{* \star *}$ & - & 3.054 ** & $5.489 * * \star$ \\
\hline & $\Delta \mathrm{ln}_{\mathrm{t}}$ & 1.513 & - & 0.22 & 2.27 & 1.816 & - & 0.704 \\
\hline & $\Delta \mathrm{B}_{\mathrm{t}}$ & 1.112 & 0.769 & - & 0.737 & 0.953 & 0.741 & - \\
\hline \multicolumn{9}{|c|}{ Poland (PL) } \\
\hline \multirow{3}{*}{ I } & $\Delta \mathrm{P}_{\mathrm{t}}$ & - & 0.263 & $3.223^{* *}$ & $7.018^{* * *}$ & - & 1.8 & $4.081^{* * *}$ \\
\hline & $\Delta \mathrm{ln}_{\mathrm{t}}$ & 0.955 & - & $2.636^{*}$ & 0.985 & 1.127 & - & 2.21 * \\
\hline & $\Delta \mathrm{B}_{\mathrm{t}}$ & 2.686 ** & 2.291 * & - & 1.34 & $2.564^{* *}$ & 2.038 * & - \\
\hline \multirow{3}{*}{$\|$} & $\Delta \mathrm{P}_{\mathrm{t}}$ & - & 1.012 & 2.216 & 0.295 & - & 0.777 & 1.49 \\
\hline & $\Delta \mathrm{ln}_{\mathrm{t}}$ & 1.98 & - & 0.659 & 1.996 & 1.743 & - & 1.04 \\
\hline & $\Delta \mathrm{B}_{\mathrm{t}}$ & 0.044 & 3.119 ** & - & 1.693 & 0.625 & $2.395^{*}$ & - \\
\hline
\end{tabular}

Note: $* * *,(* *),(*)$ indicate significance at $1 \%,(5 \%)$ and $(10 \%)$ level.

As can be seen, the Granger causality test shows the causal relationship from oil prices to production and/or inflation in both, short- and long-run terms. When we take into consideration the results of threshold cointegration under consideration, the Granger causality test based on the T-ECM models indicate the existence of causation in terms of high growth (expansion) and 
low growth (recession) regime. The T-ECM models can detect more interesting relations than the linear ECM models. They can identify the relations in terms of changes in a business cycle, showing the asymmetry not only in the case of different regimes but also in the case of different impact on analyzed economies. In this case the threshold models were able to identify the shortrun Granger causality in high regime (for Poland and France) and/or low regime (in the case of Germany and the EU). In the case of Denmark and Czech Republic the causal relationship between oil prices, production and inflation (however for Netherlands linear ECMs, the short-run Granger causality has been not found) exists.

Table 6. Granger causality analysis based on linear ECM models

\begin{tabular}{|c|c|c|c|c|c|c|c|}
\hline \multirow{3}{*}{ Effects } & \multicolumn{7}{|c|}{ Causes } \\
\hline & \multicolumn{3}{|c|}{ Short-term } & \multirow{2}{*}{$\begin{array}{l}\begin{array}{c}\text { Long- } \\
\text { term }\end{array} \\
\text { ecm }_{\mathrm{t}-1}\end{array}$} & \multicolumn{3}{|c|}{ Both (short-term and long-term) } \\
\hline & $\Delta \mathrm{P}_{\mathrm{t}}$ & $\Delta \ln _{\mathrm{t}}$ & $\Delta \mathrm{B}_{\mathrm{t}}$ & & $\begin{array}{c}\left(\Delta \mathrm{P}_{\mathrm{t}},\right. \\
\left.\mathrm{ecm} \mathrm{t}_{\mathrm{t}-1}\right)\end{array}$ & $\begin{array}{c}\left(\Delta \mathrm{ln}_{\mathrm{t}},\right. \\
\left.\mathrm{ecm} \mathrm{t}_{\mathrm{t}-1}\right)\end{array}$ & $\begin{array}{c}\left(\Delta \mathrm{B}_{\mathrm{t}}\right. \\
\left.\mathrm{e} \mathrm{em}_{\mathrm{t}-1}\right)\end{array}$ \\
\hline \multicolumn{8}{|c|}{ Denmark (DK) } \\
\hline$\Delta \mathrm{P}_{\mathrm{t}}$ & - & 2.9262 * & 1.8508 * & $13.16^{* * *}$ & - & $6.782^{* \star *}$ & $4.2919^{* * *}$ \\
\hline$\Delta \mathrm{ln}_{\mathrm{t}}$ & 2.1071 * & - & 2.3112 ** & 3.6324 * & 1.6863 & - & 2.4941 ** \\
\hline$\Delta \mathrm{B}_{\mathrm{t}}$ & 1.5822 & 0.6198 & - & 4.5344 ** & 1.6961 & 2.1692 * & - \\
\hline \multicolumn{8}{|c|}{ Netherlands (NL) } \\
\hline$\Delta \mathrm{P}_{\mathrm{t}}$ & - & 0.6688 & 0.2781 & $40.28^{* * *}$ & - & $20.27^{* * *}$ & $21.857^{* * *}$ \\
\hline$\Delta \mathrm{ln}_{\mathrm{t}}$ & 0.3858 & - & 1.197 & 8.262 *** & 4.6314 ** & - & 2.0303 * \\
\hline$\Delta \mathrm{B}_{\mathrm{t}}$ & 0.4852 & 0.006 & - & 0.7693 & 1.3264 & 0.3855 & - \\
\hline \multicolumn{8}{|c|}{ Czech Rep. (CZ) } \\
\hline$\Delta \mathrm{P}_{\mathrm{t}}$ & - & 0.0016 & 1.8884 * & $7.957^{* * *}$ & - & $4.0741^{* *}$ & 2.866 ** \\
\hline$\Delta \mathrm{ln}_{\mathrm{t}}$ & 0.3049 & - & 1.3078 & 8.856 *** & 4.6519 ** & - & $4.8005^{* * *}$ \\
\hline$\Delta \mathrm{B}_{\mathrm{t}}$ & 1.0928 & 0.0942 & - & $9.216^{* * *}$ & 4.6292 ** & $4.694^{* *}$ & - \\
\hline
\end{tabular}

Note: $* * *,(* *),(*)$ indicate significance at $1 \%,(5 \%)$ and $(10 \%)$ level.

\section{Conclusions}

In this paper, we analyzed the results of Granger causality test among oil prices, production and inflation in the framework of the threshold (T-ECM) and linear (ECM) error correction models across the set of European Union countries which are very diverse with respect to the role of oil in their economy. Several important insights emerge from this analysis.

First, the threshold cointegration analysis carried out using the residuals obtained from the estimated long-run equation with a structural change in the intercept and a change in the slope of the trend function (structural break occur in September 2008 when the financial crisis peaked) allows to identify 
the long-run relationship between production, inflation and oil prices for Germany, France, the EU and Poland. However, Polish economy reverts much faster toward its long-run equilibrium when the deviations are above the threshold value and tends to persist when the deviations are below the threshold. For Germany, France and the EU belonging to the developed countries the threshold cointegration has been found in high growth state of the economy. In the case of Denmark, Netherlands and Czech Republic the long-run relationship between production, inflation and oil prices is linear. In the case of Poland when the residuals were obtained from long-run equation with structural change in the intercept the Enders-Siklos procedure was not able to identify the long-run relationship between production, inflation and oil prices. Adding the change in the slope of the trend function in long-run equation cause the change in the residuals and then the Enders-Siklos approach was able to find the evidence for existing the long-term relationship between economic activity and prices of crude oil.

Second, both types of error correction models are capable to detect the significant relationship between oil prices, production and inflation in the analyzed European Union economies. The threshold models (T-ECM) outperform the linear ECM models because the former can reveal the asymmetric connections among analyzed variables in terms of short-run and long-run relations, while the latter cannot. When the economy is in the high growth phase of business cycle (deviations form long-run equation are above the threshold - regime 1) the Granger causality test finds evidence of short-run relationship running from oil prices to inflation (for Germany, France and Poland) and production (for France, the EU and Poland). In the case, when the economy is in the low growth phase of business cycle (deviations form long-run equation are below the threshold value - regime 2) the short-run causality from oil prices to inflation (for Germany and the EU) and production (for the EU) is identified.

Third, the Granger causality test finds the linear short-run causal relationship running from oil prices to production and inflation for Denmark and Czech Republic (with except for Netherlands). The long-run relationship running form oil prices to production was confirmed for all analyzed economies (for Denmark exists also the relation running form oil prices to inflation).

In this study we focused on testing the causal relationship between economic activity and oil prices using the ECMs with threshold cointegration and short-run asymmetries. In further studies we will concentrate on investigating the relationship in the framework of multivariate threshold models (e.g. threshold VAR and Markov switching VAR models). 


\section{References}

Bernanke, B. S., Gertler, M., Watson, M. (1997), Systematic Monetary Policy and the Effects of Oil Price Shocks, Brooking Papers on Economic Activity, 1997(1), 91-157, DOI: http://dx.doi.org/10.2307/2534702.

Chan, K. S. (1993), Consistency and Limiting Distribution of the Least Squares Estimator of a Threshold Autoregressive Model, The Annals of Statistics, 21, 520-533, DOI: http://dx.doi.org/10.1214/aos/1176349040.

Davis, S. J., Halitwanger, J. (2001), Sectoral Job Creation and Destruction Responses to Oil Price Changes, Journal of Monetary Economics, 48, 465-512, DOI: http://dx.doi.org/10.1016/S0304-3932(01)00086-1.

Edelstein, P., Kilian, L. (2009) How Sensitive are Consumer Expenditures to Retail Energy Prices?, Journal of Monetary Economics, 56(6), 766-779, DOI: http://dx.doi.org/10.1016/j.jmoneco.2009.06.001.

Enders, W., Granger, C. W. J. (1998), Unit-Root Tests and Asymmetric Adjustment With an Example Using the Term Structure of Interest Rates, Journal of Business and Economic Statistics, 16, 304-311, DOI: http://dx.doi.org/10.2307/1392506.

Enders, W., Siklos, P. (2001), Cointegration and Threshold Adjustment, Journal of Business and Economic Statistics, 19(2), 166-176,

DOI: http://dx.doi.org/10.1198/073500101316970395.

Fosten, J., Morley, B., Taylor, T. (2012), Dynamic Misspecification in the Environmental Kuznets Curve: Evidence from $\mathrm{CO} 2$ and $\mathrm{SO} 2$ Emissions in the United Kingdom, Ecological Economics, 76, 25-33, DOI: http://dx.doi.org/10.1016/j.ecolecon.2012.01.023.

Geise, A., Piłatowska, M. (2014), Oil Prices, production and Inflation in the Selected EU Countries: Threshold Cointegration Approach, Dynamic Econometric Models, 14, 71-91, DOI: http://dx.doi.org/10.12775/DEM.2014.004.

Hamilton, J. D. (1988), A Neoclassical Model of Unemployment and the Business Cycle, Journal of Political Economy, 96(3), 593-617,

DOI: http://dx.doi.org/10.1086/261553.

Hamilton, J. D. (2008), Oil and the Macroeconomy, in Durlauf S., Blume L. (eds.) The New Palgrave Dictionary of Economics, Palgrave McMillan Ltd, DOI: http://dx.doi.org/10.1057/9780230226203.1215.

Hamilton, J. D. (2011), Nonlinearities and the Macroeconomic Effects of Oil Prices, Macroeconomic Dynamics, 15(S3), 364-378, DOI: http://dx.doi.org/10.1017/S1365100511000307.

Hamilton, J. D., Herrera, A. M. (2004), Oil Shocks and Aggregate macroeconomic Behavior: The Role of Monetary Policy, Journal of Money, Credit and Banking, 36(2), 265-286, DOI: http://dx.doi.org/10.1353/mcb.2004.0012.

Herrera, A. M., Lagalo, L. G., Wada, T. (2015), Asymmetries in the Response of Economic Activity to Oil Price Increases and Decreases, Journal of International Money and Finance, 50, 108-133, DOI: http://dx.doi.org/10.1016/j.jimonfin.2014.09.004.

Orłowska, R., Pangsy-Kania, S. (2003), Cykle koniunkturalne - teoria, analiza i praktyka (Business Cycles - Theory, Analysis and the Practice), Fundacja Rozwoju Uniwersytetu Gdańskiego, Gdańsk.

Perron, P. (1989), The Great Crash, the Oil Price Shock and the Unit Root Hypothesis, Econometrica, 57(6), 1361-1401, DOI: http://dx.doi.org/10.2307/1913712.

Piłatowska, M., Włodarczyk, A., Zawada, M. (2014), The Environmental Kuznets Curve in Poland - Evidence from Threshold Cointegration Analysis, Dynamic Econometric Models, 14, 51-70, DOI: http://dx.doi.org/10.12775/DEM.2014.003. 
Stigler, M. (2010), Threshold cointegration: overview and implementation in R, Web-DOC, https://cran.r-project.org/web/packages/tsDyn/vignettes/ThCointOverview.pdf

Tsay, R. S. (1989), Testing and Modeling Threshold Autoregressive Processes, Journal of the American Statistical Association, 84(405), 231-240,

DOI: http://dx.doi.org/10.1080/01621459.1989.10478760.

\section{Asymetria zależności między aktywnością gospodarczą oraz cenami ropy naftowej w wybranych państwach Unii Europejskiej}

$\mathrm{Z}$ a r y s treści. W pracy zastosowano progowe (T-ECM) oraz liniowe modele korekty błędem (ECM) do badania krótkookresowej i długookresowej przyczynowości w sensie Grangera między produkcją, inflacją oraz cenami ropy naftowej w kontekście asymetrycznych reakcji dla siedmiu gospodarek Unii Europejskiej (tj. Niemiec, Francji, Danii, Holandii, Polski, Czech oraz Unii Europejskiej jako całości). Relacje między aktywnością gospodarczą i cenami ropy naftowej analizowano przy założeniu występowania zmian strukturalnych w równaniach długookresowych, gdzie uwzględniano załamania strukturalne w wyrazie wolnym oraz w nachyleniu funkcji trendu. Progowe modele korekty błędem (T-ECM) wskazują na asymetryczną reakcję produkcji oraz inflacji na zmiany cen ropy naftowej w przypadku Niemiec, Francji, Unii Europejskiej oraz Polski. Dla pozostałych gospodarek (tj. Danii, Holandii oraz Czech) reakcja aktywności gospodarczej na szoki naftowej jest symetryczna.

S łow a k l u c z ow e: krótkookresowa asymetria, kointegracja progowa, progowy model korekty błędem, przyczynowość w sensie Grangera, asymetryczny szok naftowy. 


\section{Appendix}

Table A.1. Results of TAR and M-TAR test for threshold cointegration in the longrun equation with one structural break in production

\begin{tabular}{|c|c|c|c|c|}
\hline & \multicolumn{4}{|c|}{ Threshold cointegration test } \\
\hline & \multicolumn{2}{|c|}{$\tau=0$} & \multicolumn{2}{|c|}{$\tau \neq 0$} \\
\hline & TAR & M-TAR & TAR & M-TAR \\
\hline \multicolumn{5}{|c|}{ Germany (DE) } \\
\hline$\tau$ & 0 & 0 & 0.0152 & -0.0131 \\
\hline$\rho_{1}$ & $-0.105[-1.889]^{*}$ & $-0.008[-0.137]$ & $-0.101[-1.806]^{*}$ & $-0.078[-1.629]$ \\
\hline$\rho_{2}$ & $-0.133[-2.173]^{* \star}$ & $-0.22[-3.887] * * *$ & $-0.138[-2.261]^{* *}$ & $-0.278[-3.251]^{* * *}$ \\
\hline$\Phi_{\mu}$ & 3.681 & $7.93^{* *}$ & 3.732 & 6.144 * \\
\hline$F\left(\rho_{1}-\rho_{2}=0\right)$ & $0.146(0.70)$ & $8.451(0.004) * * *$ & $0.244(0.62)$ & $4.973(0.03)$ ** \\
\hline Lag & 5 & 5 & 5 & 5 \\
\hline AIC & -1190.5 & -1198.6 & -1190.6 & -1195.2 \\
\hline $\mathrm{LB}(12)$ & $16.55(0.17)$ & $16.24(0.18)$ & $16.48(0.17)$ & $16.43(0.17)$ \\
\hline \multicolumn{5}{|c|}{ France (FR) } \\
\hline$\tau$ & 0 & 0 & 0.0232 & -0.0084 \\
\hline$\rho_{1}$ & $-0.105[-1.877]^{*}$ & $-0.073[-1.221]$ & $-0.062[-1.061]$ & $-0.108[-2.183]^{\star *}$ \\
\hline$\rho_{2}$ & $-0.201[-3.199]^{\star * *}$ & $-0.217[-3.697]^{* \star *}$ & $-0.233[-3.959]^{\star \star *}$ & $-0.256[-3.276]^{* * *}$ \\
\hline$\Phi_{\mu}$ & $6.453^{* *}$ & $7.33^{* *}$ & $8.165^{* *}$ & $7.159^{* *}$ \\
\hline$F\left(\rho_{1}-\rho_{2}=0\right)$ & $1.431(0.233)$ & $3.149(0.077)$ * & $4.693(0.031) * *$ & $2.824(0.094)$ * \\
\hline Lag & 2 & 2 & 2 & 2 \\
\hline AIC & -1297.01 & -1298.74 & -1297.26 & -1298.42 \\
\hline $\mathrm{LB}(12)$ & $7.31(0.2)$ & $9.10(0.11)$ & $5.97(0.31)$ & $8.50(0.13)$ \\
\hline \multicolumn{5}{|c|}{ Netherlands (NL) } \\
\hline$\tau$ & 0 & 0 & 0.0219 & 0.0126 \\
\hline$\rho_{1}$ & $-0.422[-4.244]^{* * *}$ & $-0.364[-3.722]^{* * *}$ & $-0.456[-4.136]^{* * *}$ & $-0.501[-4.187]$ *** \\
\hline$\rho_{2}$ & $-0.378[-3.859]^{\star \star *}$ & $-0.437[-4.375]^{* * *}$ & $-0.368[-4.041]^{\star \star *}$ & $-0.359[-4.113]^{\star \star *}$ \\
\hline$\Phi_{\mu}$ & 12.858 *** & 12.999 *** & $13.084^{* * *}$ & $13.5^{\star * *}$ \\
\hline$F\left(\rho_{1}-\rho_{2}=0\right)$ & $0.144(0.7)$ & $0.397(0.53)$ & $0.55(0.46)$ & $1.298(0.26)$ \\
\hline Lag & 3 & 3 & 3 & 3 \\
\hline AIC & -1096.49 & -1096.74 & -1096.89 & -1097.64 \\
\hline $\mathrm{LB}(12)$ & $12.2(0.43)$ & $11.71(0.47)$ & $12.60(0.4)$ & $12.55(0.4)$ \\
\hline \multicolumn{5}{|c|}{ Denmark (DN) } \\
\hline$\tau$ & 0 & 0 & -0.0214 & -0.0188 \\
\hline$\rho_{1}$ & $-0.444[-4.42]^{\star * *}$ & $-0.511[-4.812]^{\star \star \star}$ & $-0.458[-4.622] * * *$ & $-0.403[-4.608]^{* * *}$ \\
\hline$\rho_{2}$ & $-0.461[-5.09]^{* * *}$ & $-0.42[-4.77]^{\star * *}$ & $-0.45[-4.899]^{* * *}$ & $-0.547[-5.017]^{* * *}$ \\
\hline$\Phi_{\mu}$ & $17.692^{* * *}$ & $17.966^{* * *}$ & $17.682^{* * *}$ & $18.458^{* *}$ \\
\hline$F\left(\rho_{1}-\rho_{2}=0\right)$ & $0.023(0.88)$ & $0.631(0.43)$ & $0.005(0.95)$ & $1.482(0.22)$ \\
\hline Lag & 3 & 3 & 3 & 3 \\
\hline AIC & -973.8 & -974.4 & -973.7 & -975.2 \\
\hline $\mathrm{LB}(12)$ & $12.25(0.43)$ & $12.77(0.39)$ & $12.17(0.43)$ & $12.17(0.43)$ \\
\hline
\end{tabular}


Table A.1. continued

\begin{tabular}{|c|c|c|c|c|}
\hline & \multicolumn{4}{|c|}{ Threshold cointegration test } \\
\hline & \multicolumn{2}{|c|}{$\tau=0$} & \multicolumn{2}{|c|}{$\tau \neq 0$} \\
\hline & TAR & M-TAR & TAR & M-TAR \\
\hline \multicolumn{5}{|c|}{ Poland (PL) } \\
\hline$\tau$ & 0 & 0 & -0.009 & 0.0124 \\
\hline$\rho_{1}$ & $-0.129[-2.731]^{* * *}$ & $-0.161[-3.321]^{* * *}$ & $-0.135[-2.856]^{\star \star *}$ & $-0.18[-2.634]^{* * *}$ \\
\hline$\rho_{2}$ & $-0.075[-1.543]$ & $-0.049[-1.028]$ & $-0.069[-1.413]$ & $-0.079[-2.022]^{* *}$ \\
\hline$\Phi_{\mu}$ & 4.782 & 5.927 * & 4.947 & 5.299 \\
\hline$F\left(\rho_{1}-\rho_{2}=0\right)$ & $0.634(0.43)$ & $2.838(0.09)$ * & $0.952(0.33)$ & $1.675(0.2)$ \\
\hline Lag & 1 & 1 & 1 & 1 \\
\hline AIC & -1152.07 & -1154.29 & -1152.39 & -1153.12 \\
\hline $\mathrm{LB}(12)$ & $6.22(0.9)$ & $6.18(0.91)$ & $6.23(0.90)$ & $6.4(0.89)$ \\
\hline \multicolumn{5}{|c|}{ Czech Republic (CZ) } \\
\hline$\tau$ & 0 & 0 & -0.014 & -0.018 \\
\hline$\rho_{1}$ & $-0.208[-2.91]^{\star * *}$ & $-0.263[-3.54]^{* * *}$ & $-0.216[-3.05]^{* * *}$ & $-0.231[-3.94]^{* * *}$ \\
\hline$\rho_{2}$ & $-0.245[-3.38]^{* * *}$ & $-0.194[-2.79]^{\star * \star}$ & $-0.237[-3.24]^{* \star *}$ & $-0.206[-1.95]^{\star * *}$ \\
\hline$\Phi_{u}$ & $8.821^{* * *}$ & $8.975^{* * *}$ & $8.685^{* *}$ & $8.644^{* *}$ \\
\hline$F\left(\rho_{1}-\rho_{2}=0\right)$ & $0.159(0.69)$ & $0.517(0.47)$ & $0.051(0.82)$ & $0.047(0.83)$ \\
\hline Lag & 2 & 2 & 2 & 2 \\
\hline AIC & -1040.1 & -1040.5 & -1040.0 & -1039.99 \\
\hline $\mathrm{LB}(12)$ & $11.89(0.45)$ & $11.55(0.48)$ & $11.84(0.46)$ & $11.76(0.46)$ \\
\hline \multicolumn{5}{|c|}{ European Union (EU) } \\
\hline$\tau$ & 0 & 0 & -0.0134 & 0.0068 \\
\hline$\rho_{1}$ & $-0.162[-2.973]^{* * *}$ & $-0.059[-1.046]$ & $-0.163[-3.053]^{* * *}$ & $-0.041[-0.481]$ \\
\hline$\rho_{2}$ & $-0.187[-3.504]^{\star * *}$ & $-0.262[-4.992]^{\star \star *}$ & $-0.188[-3.436]^{* * *}$ & $-0.201[-4.575]^{* * *}$ \\
\hline$\Phi_{u}$ & $10.662^{* * *}$ & $12.979^{* * *}$ & $10.666^{* * *}$ & $10.648^{* * *}$ \\
\hline$F\left(\rho_{1}-\rho_{2}=0\right)$ & $0.109(0.74)$ & $7.309(0.01)^{* \star *}$ & $0.115(0.73)$ & $3.021(0.08)^{*}$ \\
\hline Lag & 0 & 1 & 0 & 1 \\
\hline AIC & -1264.22 & -1264.56 & -1264.23 & -1260.38 \\
\hline $\mathrm{LB}(12)$ & $13.62(0.33)$ & $16.49(0.17)$ & $13.55[0.33]$ & $14.63[0.26]$ \\
\hline
\end{tabular}

Note: $* * *, * *$ and $*$ denote significance at $1 \%, 5 \%$ and $10 \%$ level respectively; in parentheses the $t$-statistics are given; in brackets the $p$-values are given.

Dynamic Econometric Models 16 (2016) 65-86 